\title{
The Increasing of Students' English Speaking by Using Community Language Learning (CLL) through Students English Association of LP3I (SEAL) at Politeknik LP3I Medan
}

\author{
Ramadani $^{1}$, Andrysyah ${ }^{2}$, Nurul Husnah Harahap ${ }^{3}$, Rani Rakasiwi ${ }^{4}$ \\ ${ }^{1,2}$ Politeknik LP3I Medan \\ ${ }^{3,4}$ AMIK Medicom Medan \\ ramadanijawa92@gmail.com,Andrysyah29@gmail.comunaharahap@yahoo.com,ranirakasiwi3@gmail.com
}

\begin{abstract}
This study dealt students' English speaking by using Community Language Learning (CLL) through Students English Association of LP3I (SEAL). It used qualitative research design. It was conducted descriptively. This study aimed to know the increasing of students' English speaking by using Community Language Learning (CLL) through Students English Association of LP3I (SEAL) at Politeknik LP3I Medan. The subjects were 55 students of Politeknik LP3I Medan. The use of instruments in this study was observation, interview and documentation. The theory of Koba, Ogawa \& Wilkinson was used in this study. The data were analyzed by Miles, Huberman and Saldana analysis. The result of this study was Community Language Learning (CLL) had good result for students' learning and can increase students' English speaking at Politeknik LP3I Medan. This learning method was appropriate implemented to students of Politeknik LP3I Medan. Based on the data, all of response and result of this learning method got positive result and effect through the students of Politeknik LP3I Medan. This learning method can also upgrade students' knowledge in speaking and got more vocabulary after implementing this activity. CLL can make the students happy and enjoy in studying English without forcing them to speak English. CLL can also make students brave and self-confidence to speak up in front of public.
\end{abstract}

Keywords

factor affecting speaking

ability; community

language learning (CLL);

student english

association of LP3I

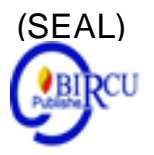

\section{Introduction}

Most of students consider that learning English is very difficult to understand and feel unimportant with the existence of English at the moment. In fact, English is very important in the world of work. Students of Politeknik LP3I Medan think that English is one of the difficult subjects because these students are not able to speak English while English has an important role in Politeknik LP3I Medan. Students are required to be able to speak English after graduation because Politeknik LP3I Medan has equipped students with knowledge in English every semester where students must face English subject for four semesters which have four credits in semester one and two, two credits in semester three and four. Even though, English has been implemented in four semesters, some students cannot speak English optimally. Inability of students to speak English, this will be also a problem for students' Human Resources (HR) in finding work. As is well known Politeknik LP3I Medan is one of the tertiary institutions which has the most work placements in North Sumatra. Seeing the phenomenon in the field most of students of Politeknik LP3I Medan have not been able to speak English, if this continues then it does not rule out, Politeknik LP3I Medan will cause 
obstacles in the work placement of alumni because Politeknik LP3I Medan has job placement targets in national and even international level.

This study aims to find out how to improve students' English speaking by using Community Language Learning (CLL) through the Student English Association of LP3I (SEAL) at Politeknik LP3I Medan and this research is also to realize the flagship program of the LP3I Polytechnic in Medan and facilitate the division of Cooperation and placement work. Cooperation and Placement (C\&P) has job in placing the work of the alumni. The Importance of Research is carried out because fluency in speaking English is one of the requirements for jobseekers if they want to work in a benefit company. Politeknik LP3I Medan has a superior program that is "tepat dan cepat kerja" where every student is guaranteed work placement after graduating from college. Politeknik LP3I Medan also has a Cooperation and Placement $(\mathrm{C} \& \mathrm{P})$ division where the division is tasked with placing the work of every student who has graduated. With this program Politeknik LP3I Medan must prepare good human resources, one of which is the student's fluency in speaking English. With English fluency, students will have high competitiveness and will facilitate Cooperation and Placement (C\&P) in placing the work of alumni. Previous research looked at students' interest in speaking English using Community Language Learning (CLL). Based on previous research students' ability to speak English has a high interest, so the achievement of speaking English students rose significantly. CLL is also capable of achieving English speaking students. Research that will be investigated by researchers is to find out how to improve students' speaking English by using Community Language Learning (CLL) through the Student English Association of LP3I (SEAL).

\section{Review of Literatures}

Fisher and Frey (2007:16) adopted the speaking definition put forth by Cooper and Morreale: "Speaking is the uniquely human act or process of sharing and exchanging information, ideas, and emotions using oral language. Whether in daily information interactions or in more formal settings, communicators are required to organize coherent messages, deliver them clearly, and adapt them to their listeners". In addition, Hughes (2002:135) states that speaking is fundamentally an interactive task; speaking happens under real time in processing constrains and it is more fundamentally linked to the individually who produces it.

\subsection{Factor Affecting Speaking Ability}

The students should learn how to be communicative in speaking English. They learn more speaking skills and develop some attitude toward speaking achievement. Therefore, the speaker must know the topic of the conversation in order to give or share of their information.

To reach the target language, Brown (1994: 4) devided some factors which affect speaking, they are:

1. Chronological Age: Most students indicate that the age of begining speaking success that is intellectual, personality, and social factor. Therefore, it is important for teacher to consider whether the students were ready to speak or not

2. Grammar

Grammar is the description of the structure of a language and the way in which linguistic unit such as words and phrases and combined to produce sentence in the language. 


\section{Vocabulary}

Numan said that Vocabulary is more than lists of target language words. A spoken word is a sound of sequence of sound, which communicate in idea to the mind of another person. In order to communicate those ideas precisely, a speaker should express them with precise word rather than general word.

Vocabulary is a list of words in English with different meaning and function that people use to refer to an object and to make a sentence. Vocabulary is the very basic thing about English that people should learn at first. This is because vocabulary is needed when we want to say or pointing at something. "Vocabulary is a language central and of critical importance of typical language" (Nilawati in Purba, 2020).

\section{Fluency}

Looks at fluency as the ability to fill the time with talk. In this definition, the speaker can use the time of talking most productively. The definition of fluency is derived aa the ability of an individual to speak without undue hesitation.

5. Comprehension

Comprehension is the minds act or power of understanding. It means that the comprehension will be as contrasted with the ability to perceive and pronounce words without reference to their meaning. Clark and clark make a simple meaning of comprehension as the building the meaning from sounds. It means what the listener hear and understand from a speaker is to show his comprehension.

\subsection{Community Language Learning}

CLL is primarily based on the principles of teaching English for communication. To this end, learners' needs and feelings are addressed with due regard in every aspect of the teaching process. It is obvious that CLL differs from traditional language teaching methods with the techniques it employs to reduce learner's anxiety and help them produce sense of security (Koba, Ogawa \& Wilkinson, 2000). Some of the significant CLL principles can be outlined as follows:

- It is important to establish a mutual relationship between the learner and the teacher in order to create a safe learning environment; students tend to learn more effectively when they feel secure.

- Language is for communication. Therefore, students should be encouraged to communicate as frequently as possible during the lesson.

- The teacher stands behind the students in order to facilitate the learning process.

- The teacher should respect the learners' level of confidence and transmit to them what needs to be done to be successful

- Learners need to know the limits of a teaching activity so that they feel more secure.)

- As the teacher and the learners are whole persons, they can share learning experiences, thus getting to know one another and building a sense of community.

- Considering that each learner is unique, the teacher, as a counselor, values the learners and their ideas; s/he and always listens to them without giving any advice in order to understand how they feel about the learning process. 
- A learner as a client uses his native language to make the meaning clear and to build a bridge from the known to the unknown, since understanding classroom interaction facilitates learning.

- Learners are required to attend to one task at a time and are offered a quiet reflection period in order to learn.

- Learners have a choice in what they want to practice, as they have an inner wisdom about where they need to improve.

- Students work in groups to feel a sense of community; thus, they can learn from each other as well as the teacher. Cooperation, rather than competition, is encouraged.

- The teacher should correct the errors that learners have produced in a nonthreatening way.

- By reading their sentences to the other members of the class, learners develop a sense of community and build trust, which helps to reduce the threat of the new learning situation.

- When material is new or too familiar, learning tends not to take place. Retention will best take place somewhere in between novelty and familiarity.

- Apart from the language, learners also reflect on what they have experienced. Thus, they have an opportunity to learn about the language, about their own learning, and about how to learn from one another in a community.

- The syllabus is generated primarily by students in the beginning stages. Students are more willing to learn when they have created the material themselves (LarsenFreeman \& Anderson, 2011, pp. 91- 93).

In CLL, students learn not only how to use the target language communicatively, but also how to take responsibility for their own learning. Such learning takes place in a communicative situation where teachers and learners are both involved in an interaction in which both experience a sense of their own wholeness (Curran, 1972, as cited in Richards \& Rodgers, 2002, p. 90). The stages of learning in CLL identified by Charles Curran are listed by Marshall and Baker (2000) as follows: (1) Students don't know the target language and are completely dependent on the teacher. (2) With the aid of the teacher, students begin to use the new language. (3) Students use language independently and confidently, understand better, and may even begin to resist intervention by the teacher. (4) Students are able to express themselves more elaborately, although they may be aware of gaps in their knowledge. (5) Students are able to continue their learning without assistance (p. 37). 


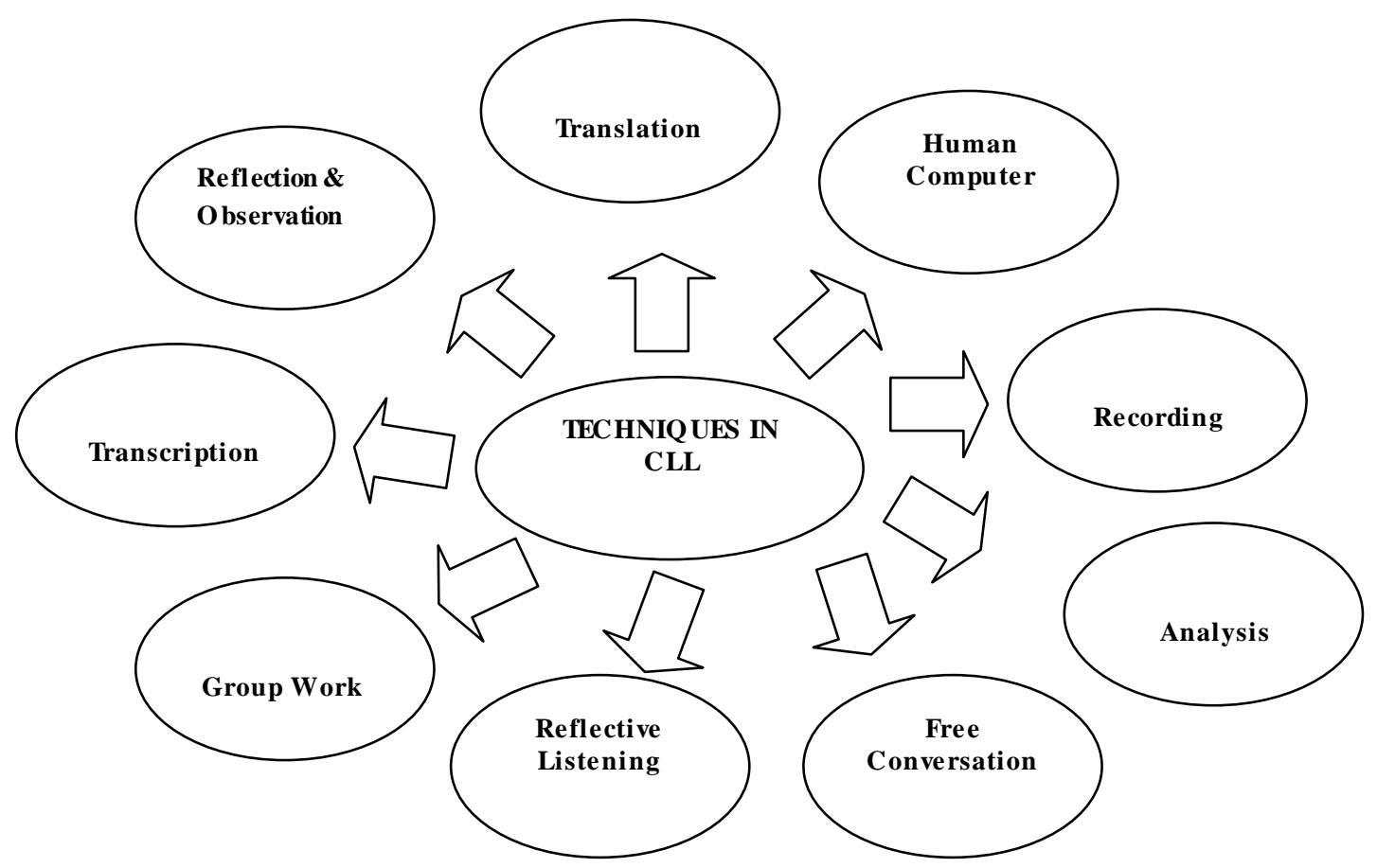

Figure 2. Techniques on CLL (Richards \& Rodgers, 2002)

\subsection{Student English Ass ociation of LP3I (SEAL)}

SEAL is a Student activity unit that directs skills activities in the use of English. These activities include learning in extra-curricular classes and competitions with nuances of English competition. SEAL is an extra-curricular which is held every Saturday at Politeknik LP3I Medan where students will explore English skills especially in English speaking skills. SEAL also explores the potential of students to appear in public by using English. There are a number of skills targeted by the SEAL that are students able to compete highly in a race that will be held by an institution outside of Politeknik LP3I Medan, with this extra-curricular students will be better prepared to follow competition. SEAL has several concentrations, namely debate, news casting, speech and story-telling where each member has the right to choose the concentration they are interested in.

\section{Research Method}

The research method that used in this study was qualitative analysis. Moleong (2004: 6) states qualitative research as research that intends to understand phenomena about what is experienced by research subjects such as behaviour, perception, motivation, actions etc., holistically and by means of descriptions in the form of words and language in a particular context naturally and by utilizing various scientific methods. The data of this study were the utterances of students in interview after activity of the Student English Association of LP3I (SEAL) as many as 55 people during English conversation in class. Data will be analyzed using the method of Miles, Huberman \& Saldana (2014: 33). There are three phases of bias analysis data seen in the figure below: 


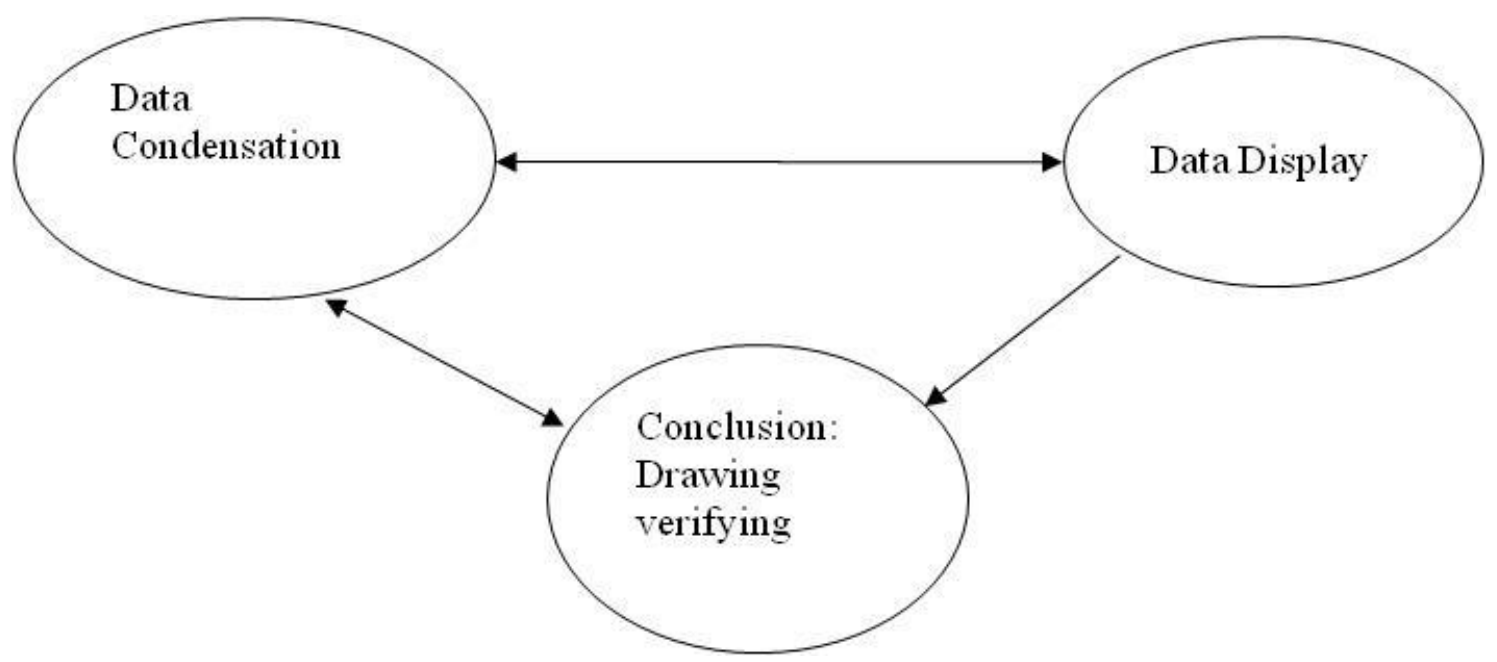

Figure 2. Miles, Huberman and Saldana's Interactive Model (2014:33)

\section{Discussion}

After analyzing the data, the researcher found that the students were interesting to join and study in this activity. The students had good response from this activity. The researcher found also that the students were spirit to study and confidence to convey the material in English in front of their friends. From fifty five students, fifty three had good response from this activity. The researcher got this data from his interview to the students. The students had enthusiastic to speak English without caring the grammar. This activity also had good effect for students who were never speaking in front of class. This teaching method can make the students more confidence with themselves to speak or practice their English to their friends in the class. This activity also did not force them to speak English but can encourage them to increase their English. This activity can make students sharing about their English all this time and also ask their friend if one of them did not understand about something in English. This activity was their opportunity to speak up freely in front of their friends. Factually, this learning method encouraged them to speak. Most of them said that, the following was their expression about response of increasing their English. The interviewer asked the students this question "Does this activity encourage you to speak?", then the student answered "yes, because I really rarely speak English in myself so this is opportunity for me to upgrade my English ability" from the student's answer we know that he gave positive response about this learning method. We see his answer about "I really rarely speak English in myself......" from that expression we know that he rarely spoke English in his daily life. It means he was not interested to speak English previously so he rarely spoke English in his daily life. Because of this activity, he spoke English in this activity, let see his expression "this is opportunity for me to upgrade my English ability" by joining this activity, the student felt helped to upgrade and increase his speaking in English. This activity also had big opportunity for students in practicing their English one to each other. By joining this activity every week, the students would always practice their English every day. Then, English would be their habit in their life and the students practiced it every time, not only in this activity but the students would practice it every activity. Then, this activity also made the students self-confidence in their speaking. The researcher asked the question "does this activity make yourself confidence to speak?" after researcher asked the question, the student answered positively. The following 
was a representative response from the students that have positive response "yes, because studying English is relax and happy so we are more confidence" from student's answer above, we know that the student felt relax when they studied English. The students will feel happy in this activity when they felt relax in studying.

This method was successful to make the students relax in studying and also encourage them to upgrade their English. From the expression "we are more confidence" it means that the students braved to practice their English with their friends. One of student's obstacles was their self confidence to practice their English. Self confidence was one of the most important things in increasing student's English. If they have lack of confidence in speaking English, automatically the students will never practice their English in their daily life. Then, there's one of students answer "this activity makes me be brave to speak English while trying be confidence when I can't use all of tenses" from this expression, actually this student cannot speak English well because lack of grammar. She is always afraid to speak English because she doesn't have good grammar. Because of it, she was seldom to practice her English. In the field, the obstacle of students not to practice their English was afraid to do wrong in their speaking. But in this activity the students had good confidence to speak English. We can know from this expression "this activity makes me be brave to speak English while trying be confidence........" because of this activity, the student felt brave without caring of grammar. This activity had good effect to the students who never practiced their English.

This activity became their opportunity to practice their English. Because this activity the lecturer did not demand the students to be able to speak English perfectly. The important thing from this activity, the lecturer invited the students to speak English freely without caring the grammar. Then, the researcher asked the student their opinion about this activity. The researcher asked "what do you think of this activity?" almost all of them had good opinion about this activity. In the class, all of students looked like interested and enjoy with this activity. The following was the representative data from the students. The student answered "I think very interesting, so nice activity to increase the pronunciation, to know more vocabulary, make the lazy people become spirit for studying English of this activity" from the student's answer, we know that this activity was helpful for them to increase their knowledge about English. Based on her answer, she got knowledge about pronunciation and vocabulary from this activity. Previously, the students were not interested to study English but campus asked the students to speak English every time in campus zone. By using this strategy, the students were happy to study and they wanted to practice their English with their friends without forcing them to speak up. They enjoyed with this activity. From her expression "........so nice activity to increase the pronunciation, to know more vocabulary,......" it meant that this activity can improve their pronunciation and vocabulary. We know that pronunciation and vocabulary were two important components in speaking English. In speaking we must need many vocabularies to speak much. Then to make our speaking was good, we should have good pronunciation to make our speaking was clear and our interlocutor understood what we said. For next question the researcher asked the students about the increasing of their English from this activity. All of the students' responses are positive about this activity. This activity was extremely positive in increasing their English. The researcher asked "does this activity help your English to increase?", from the interviews' data, all of them answer "yes". The following was representative complete answer among them "yes, this activity really helps me to increase in speaking English. Then, just memorize tense is not really help, therefore, I am not really exiting when studying grammar. But when doing this activity my mood and spirit up to" from the explanation of her answer is clear that this activity is helpful for them to increase their English. They rare practice their English all this time because of grammar. By implementing this activity, the 
students were more confidence and brave to practice their English. We can know from her expression about studying English. It was not interesting and making her mood was bad. Common case from students who not interest to practice their English caused by grammar that make them confused in arranging good sentence. We can see from the students' expression "..........I am not really exiting when studying grammar........" this was bad response from the students in studying grammar.

By using this method, the students were happy and interested to study English in this activity without caring the grammar. In this activity, the students must speak up one by one without thinking about good grammar. By using this method, the students became brave and self-confidence to practice English in their environment. The last question that researcher asked the students about the effect that they got after this activity. The researcher wanted to know, was there any positive effect the students got after they did the activity? The researcher asked them the following question "what effect do you get after this activity?" all of the students that participated in this activity, the students felt the effect from this activity. The students felt their English be better than previously. Previously, the students felt shy to practice their English because the students had lack of self-confidence to practice their English in their environment. But after this activity the students said they have more confidence to practice their English in their daily life. The following was their representative answer from the students "before doing this activity just now, I feel so lazy and begin activity I feel fresh and so happy" from the answer, the students felt lazy to study because they think that the activity will make them bored. Factually, this activity make them feel fresh and spirit to study and this activity also made the students have more vocabulary and more knowledge from this activity. Then from this activity, the students can upgrade their English time by time.

\section{Conclusion}

Based on the findings and discussion, the researcher can conclude that Community Language Learning (CLL) had good result of students' learning and can increase students' English speaking at Politeknik LP3I Medan. This learning method was appropriate implemented to students of Politeknik LP3I Medan. Based on the data, all of response and result of this learning method got positive result and effect through the students of Politeknik LP3I Medan. This learning method can also upgrade students' knowledge in speaking and got more vocabulary after implementing this activity. CLL can make the students happy and enjoy in studying English without forcing them to speak English. CLL can also make students brave and self-confidence to speak up in front of public.

\section{References}

Brown, H.D. (1994). Teaching by Principle. Englewood Cliffs, NJ; Prentice Hall. Koba, N., Hughes, Rebecca. 2006. Spoken English, TESOL, and applied Linguistics: Challenges for Theory and Practice. Great Britain: CPI Antony Rowe

Larsen-Freeman, D., \& Anderson, M. (2011). Techniques and principles in language teaching (3rd ed.). London, England: Oxford University Press

Miles, MB, Huberman, A.M, dan Saldana, J. Qualitative Data Analysis, A Methods Sourcebook, Edition 3. USA: Sage Publication.

Moleong, Lexy J.1995. Metodologi Penelitian Kualitatif. Bandung: PT. Remaja Rosdakarya Natalia, S, 'CLL (Community Language Learning) Method and Students' Interest towards 
Students' Speaking Ability," English Language Education and Literature : pp.105 $110,2017$.

Ogawa, N., and Wilkinson, D. (2000). Using the Community Language Learning Approach to cope with Language Anxiety. The Internet TESL Journal, 6 (11).

Purba, C., N. (2020). Improving Students' Listening Comprehension through New Vocabulary Learning. Budapest International Research and Critics Institute-Journal (BIRCI-Journal). P. 1270-1279.

Ramlan. (2018). Some Steps for Language Maintenance in the Society and Individual. Budapest International Research and Critics Institute-Journal (BIRCI-Journal) Vol I (2): 62-71.

Richards, J. C., \& Rodgers, T. S. (2002). Approaches and methods in language teaching (2nd Ed.). New York, NY: Cambridge University Press.

Sari, A.S.P., Sembiring, R.K. (2019). Improving Students' English Speaking Skill Through the Implementation of Talking Stick Method to the Fifth Grade Students of State Primary School 028226 Binjai. Budapest International Research and Critics in Linguistics and Education (BirLE) Journal Vol 2 No (4): 507-513.

Siregar, M., and Eswarny, R. (2020). Improving Students' Achievement in Speaking Monologue Text by Using Video. Budapest International Research and Critics InstituteJournal (BIRCI-Journal) Vol 3 (2): 1343-1351.

Syakur, A., Sugirin, Margana, Junining, E., and Sabat, Y. (2020). Improving English Language Speaking Skills Using "Absyak" On-Line Learning Model for Second Semester in Higher Education. Budapest International Research and Critics in Linguistics and Education (BirLE) Journal Vol 3 (2): 684-694.

Syakur, A., Zainuddin, H.M., and Hasan, M.A. (2020). Needs Analysis English For Specific Purposes (ESP) for Vocational Pharmacy Students. Budapest International Research and Critics in Linguistics and Education (BirLE) Journal Vol 3 (2): 724-733. 